


JEROME L. SCHWARTZ, Dr.P.H.

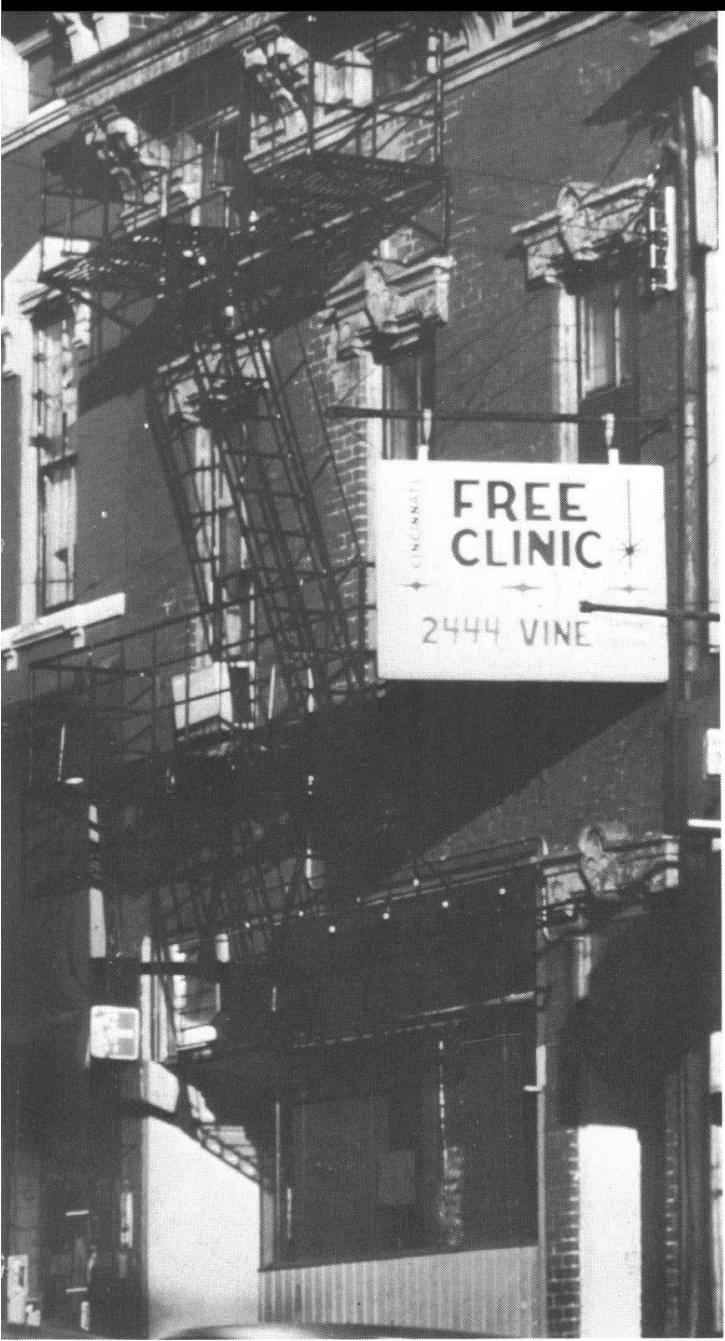

A new form of health care de-

Dr. Schwartz is visiting professor of public health and preventive medicine, West Virginia University School of Medicine, Morgantown, and director of the $\mathrm{Na}$ tional Free Clinic Survey. He is also a member of the executive committee of the National Free Clinic Council. When this survey was initiated, he was coordinator of the University of California (Berkeley) Health Services Research Program, Institute of Business and Economic Research, supported by California Health Services Center grant No. P02 HS-00234-02 from the National Center for Health Services Research and Development, Health Services and Mental Health Administration. Tearsheet requests to Dr. Jerome $L$. Schwartz, Institute for Health Research, 3101 Benvenue, Berkeley, Calif. 94705. livery has appeared on the medical care scene-the free or neighborhood volunteer clinic. All but a few of these programs were initiated without financial support and have depended on volunteer health professionals, paramedical personnel, and community people. Sixty new centers offering medical care were launched during 1970, and about two dozen more started during the first 4 months of 1971 , increasing the total number of volunteer clinics to at least 135 . They are located in all sections of the United States and Canada. California had more clinics (42 in December 1970) than any other State. There were five in Cincinnati, nine each in Chicago and Seattle, and 16 in the Los Angeles area.

\title{
Purposes of the Survey
}

In February 1970 I began the first national survey of free clinics. The purposes of the survey 
were to identify all known free clinics and to gather the following information about each: how and when the organization started; philosophy and purposes; organizational setup and policy making; selection and occupation of board members; description of clinic quarters; staffing; types of services (medical, dental, drug, psychological, and others); patient utilization and characteristics; financing, budgets, and salary arrangements; and the attitudes and reactions of various segments of the community toward the clinic.

This initial report of the national survey covers free medical clinics started by the end of 1969, a total of 59, of which 50 were operating at the end of 1970. A more comprehensive report including a list of clinics will appear in a forthcoming publication (1), and a second survey will include clinics initiated during 1970.

\section{Survey Methods}

The survey was conducted largely by telephone, although a number of clinics originally filled out a mail questionnaire and 24 centers were visited. Correspondence, written material, news clippings, and visits and discussions with persons who had been patients, staff members, or visitors at clinics rounded out the information.

The data shown in the tables were collected during 1970 and reflect the operation of clinics at that time. Some tables include clinics that are no longer in operation. Because many centers did not make ongoing counts of such information as age of patient, ethnic groups, or hours worked by professionals, respondents were asked to make estimates. Despite these limitations the data portray an overview of free clinics founded during 1967-69.

\section{Initiation and Location}

The first free clinic, the Haight-Ashbury Free Medical Clinic, was launched during the summer of 1967 in San Francisco $(2,3)$. It closed in September 1967 , but reopened 5 weeks later. Four other clinics began services during 1967 in Cincinnati, Detroit, Seattle, and Vancouver (Canada) and have been in continuous operation since. During 1968 clinics were opened in a number of other cities: Los Angeles, Atlanta, Boston, St. Louis, Chapel Hill and Durham, N.C., Chicago, Washington, D.C., Las Vegas, Portland, Ore., Denver, Philadelphia, Minneapolis, Champaign, Ill., and Montreal and Winnepeg, Canada. Five clinics were opened in 1967, 24 in 1968, and 30 in 1969, as shown in the following tabulation:

\section{Table 1. Free clinics initiated in 1967-69, by region and State}

\begin{tabular}{|c|c|c|}
\hline Region and State & Number & Percent \\
\hline 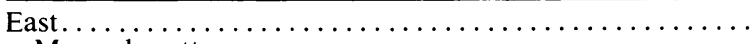 & 4 & 7 \\
\hline Massachusetts $\ldots \ldots \ldots \ldots \ldots \ldots \ldots \ldots \ldots \ldots \ldots \ldots$ & 2 & \\
\hline 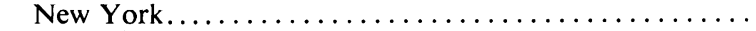 & 1 & .... \\
\hline Pennsylvania $\ldots \ldots \ldots \ldots \ldots \ldots \ldots \ldots \ldots \ldots \ldots$ & 1 & \\
\hline 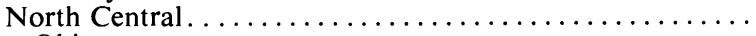 & 14 & 24 \\
\hline 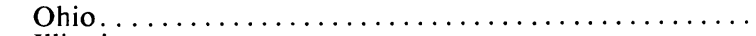 & 3 & $\ldots \ldots$ \\
\hline Illinois & 5 & $\ldots \ldots \ldots$ \\
\hline 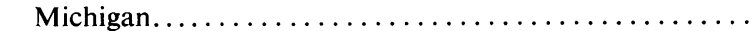 & 2 & $\ldots \ldots \ldots$ \\
\hline 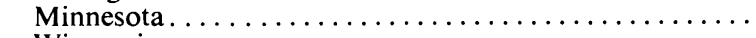 & 2 & $\ldots \ldots$ \\
\hline 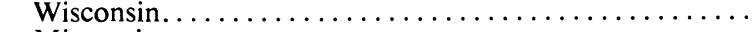 & 1 & ..... \\
\hline Missouri. $\ldots \ldots \ldots \ldots \ldots \ldots \ldots \ldots \ldots \ldots \ldots \ldots \ldots$ & 1 & ...... \\
\hline South and Southwest $\ldots \ldots \ldots \ldots \ldots \ldots \ldots \ldots \ldots \ldots \ldots$ & 7 & 12 \\
\hline District of Columbia $\ldots \ldots \ldots \ldots \ldots \ldots \ldots \ldots \ldots \ldots \ldots$ & 2 & \\
\hline North Carolina $\ldots \ldots \ldots \ldots \ldots \ldots \ldots \ldots \ldots \ldots \ldots$ & 2 & $\ldots .$. \\
\hline 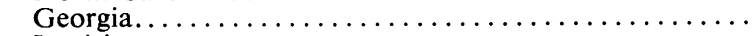 & 1 & ... \\
\hline Louisiana.$\ldots \ldots \ldots \ldots \ldots \ldots \ldots \ldots \ldots \ldots \ldots$ & 1 & $\ldots .$. \\
\hline 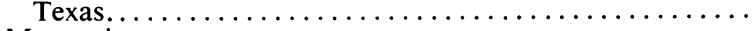 & 1 & … \\
\hline 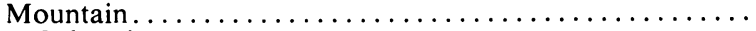 & 3 & 5 \\
\hline$\ldots \ldots \ldots \ldots \ldots \ldots \ldots$ & 1 & \\
\hline New Mexico $\ldots \ldots \ldots \ldots \ldots \ldots \ldots \ldots \ldots \ldots \ldots \ldots \ldots$ & 1 & $\ldots .$. \\
\hline 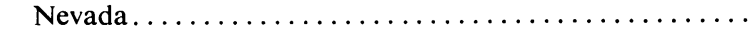 & 1 & $\ldots .$. \\
\hline 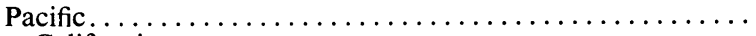 & 26 & 44 \\
\hline 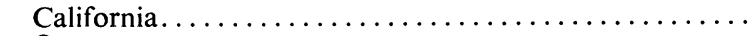 & 18 & \\
\hline Oregon $\ldots \ldots \ldots \ldots \ldots \ldots \ldots \ldots \ldots \ldots \ldots \ldots \ldots \ldots \ldots \ldots \ldots$ & 1 & $\ldots$ \\
\hline Washington $\ldots \ldots \ldots \ldots \ldots \ldots \ldots \ldots \ldots \ldots \ldots \ldots \ldots$ & 6 & \\
\hline 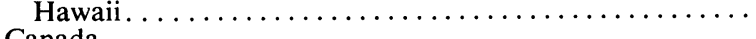 & $\frac{1}{5}$ & $\cdots \cdots$ \\
\hline 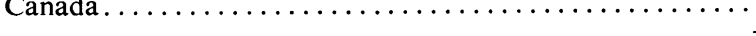 & $\mathrm{J}$ & \\
\hline Total. ....... & 59 & 100 \\
\hline
\end{tabular}

\section{7-69,} period ending-

June 1967

December 1967

June 1968

June 1969

Total

in January 1971 only 50 of the 59 clinics were in opuration. Three clinics closed in 1969 , four clinics were not in operation in January 1971, and two others terminated their medical programs.

Thirty percent of the clinics initiated in 1967-69 were located in California, but there were also volunteer clinics in 19 other States, in the District of Columbia, and in Canada (table 1).

\section{Definition of Free Clinics}

One point to consider in a discussion of free clinics is that there have been no-pay programs for years at charity and county
December $1969 \ldots \ldots \ldots \ldots \ldots . \ldots . \ldots . \ldots$ 
hospitals, public schools, welfare programs, and so on; and in recent years, neighborhood health centers, sponsored by the Office of Economic Opportunity, and Public Health Service comprehensive health centers have provided free care to indigent families. There have also been alcohol, drug, and mental health programs; maternal and infant care programs; the Indian Health Service; and military, veteran, and Public Health Service hospital programs. Senators and Representatives also go to their free clinics; for example, Walter Reed Hospital.

What then is a "free clinic"? I formulated a working definition of a free clinic, based on seven criteria:

1. Direct delivery of medical care, dental care, or psychological and drug abuse care.

2. Presence of a professional relevant to the service provided.

3 . Services available to everyone without redtape or eligibility tests.

4. In general, no direct charges, although small charges for specific services (50 cents or $\$ 1$ ) or donations may be requested.

5. At least some volunteer professionals on the staff.

6. Specified hours of service.

7. Care provided from a facility.

Excluded were in-residence and methadone programs for narcotic addicts; ministerial counseling; drop-in or referral centers; medical school, hospital, or health department outreach centers; and programs aimed at a categorical disease or defined population.

\section{Types of Centers}

The 59 free and volunteer clinics founded between 1967 and 1969 were classified into four broad types, distributed as follows: neighborhood, 23; street, 22; youth, 10; and sponsored, 4 . Most of the early clinics were the street type (three of the five formed in 1967 and seven of the first 12). However, from June through November 1968, 11 neighborhood-type clinics were initiated, bringing the total number of neighborhood clinics to 13 of the 29 clinics formed by the end of 1968. Of the others, 12 were the street type and four, the youth type. The first sponsored clinic was not launched until January 1969.

Neighborhood-type clinics. These clinics were started either by a group of residents in a specific neighborhood or housing project or by a political organization (for example, Black Panthers, Young Lords, Young Patriots, and Latin American Defense
Organization). Many of these centers served minority persons in areas where few health resources were available.

They provided medical care to families, with most patients being young children, pregnant women, or older people from the immediate neighborhood. Only a few offered care for hard-drug problems. Mental health services were offered in one-third of the neighborhood clinics, and half of them had "rap" programs. Almost all of these clinics had community boards, with neighborhood residents participating in policymaking.

Street-type clinics. In general, these clinics offered some kind of drug care and had many patients with drug-related illnesses. The most important diagnoses were venereal disease, pregnancy tests, urinary infections, and hepatitis; and counseling on

Consultation at the Spurgeon Jake Winters People's Medicare Care Center, a Black Panther clinic in Chicago. Photo by Paul Sequeira

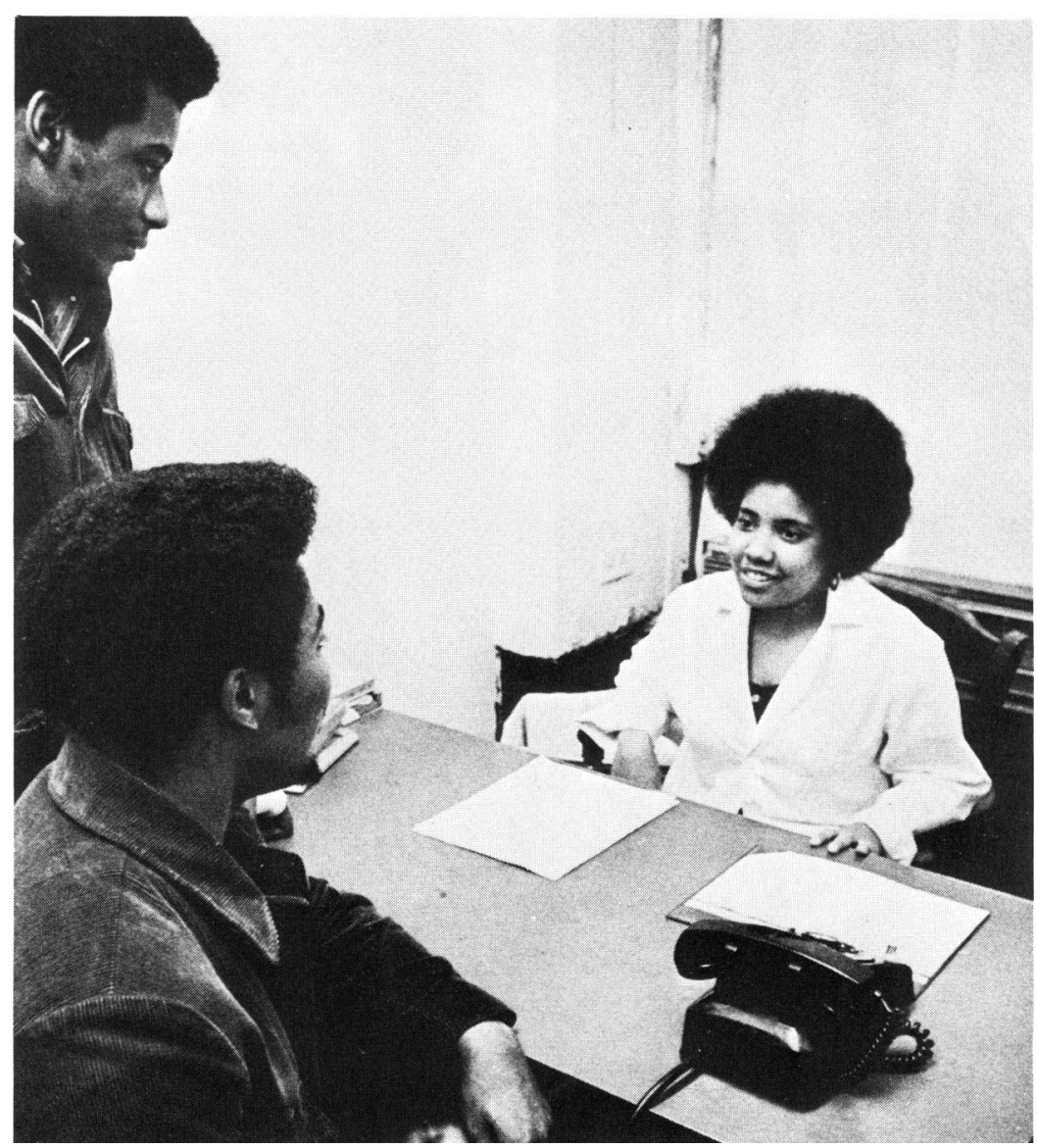


Supply section of the Young Patriots' Community Health Service in Chicago. Photo by Paul Sequeira

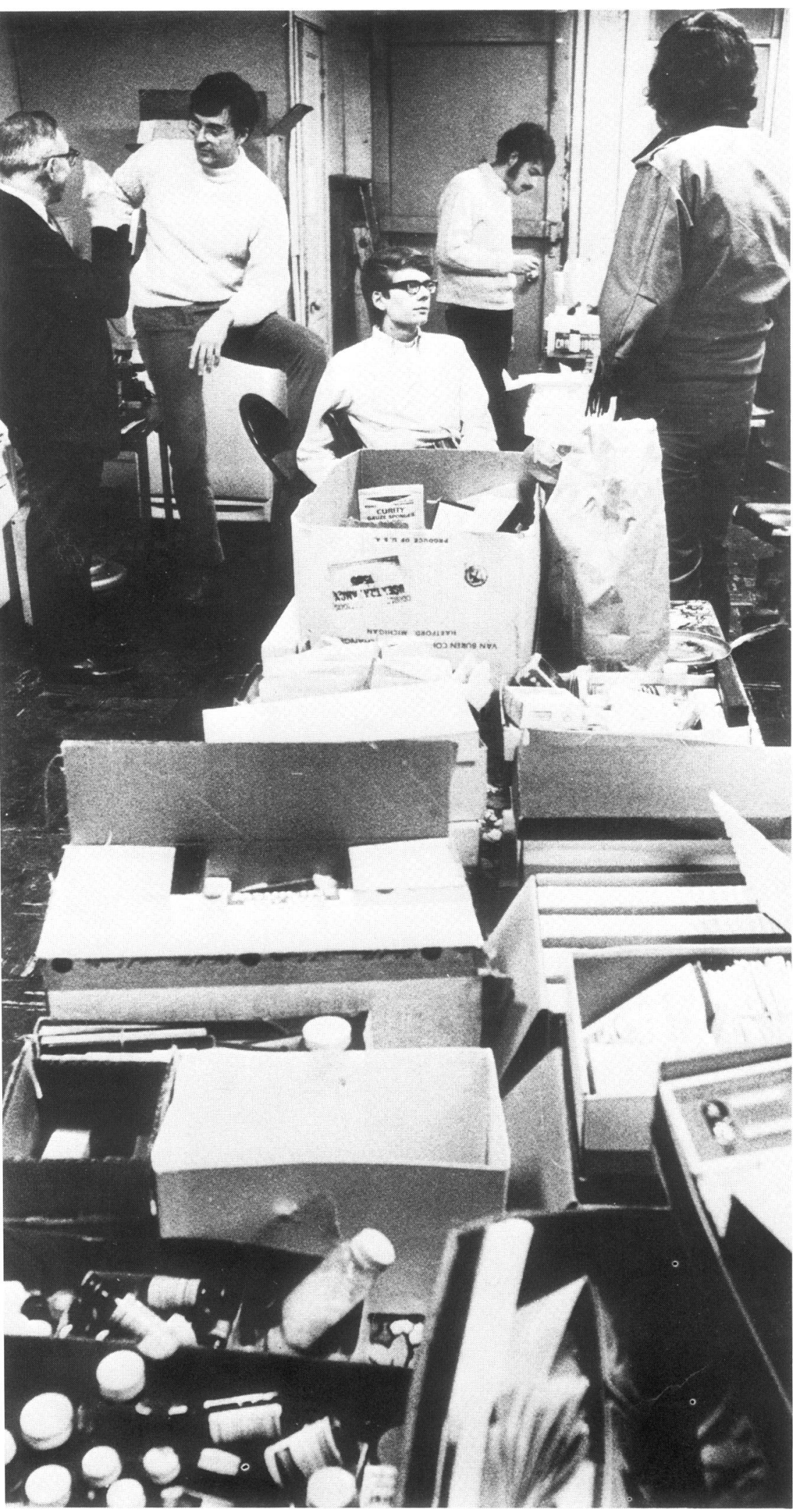

abortion was given. Psychological problems tended to be serious, and almost all these clinics had volunteer psychiatrists.

The largest age group of patients included 19- to 24-yearolds, with the 16- to 18-year age group usually next. These clinics had few patients who were young children or people over 35 years old. Many of the clinics were near a college campus or in the hippie section of town. Patients generally came from all over the city or the suburbs, and some were transients.

In street-type clinics, one cannot generalize about how decisions are made and by whom. Many did not have a board of directors, and some had a board that was inactive or on paper only for incorporation purposes. Policies were often decided by the staff, the administrator, or the medical director. Some clinics, however, had functioning boards composed of staff, hippie or street people, students, and community people.

Youth-type clinics. These clinics were generally organized by adults, service clubs, or official bodies (for example, mayor's committee, drug council) because of their concern about drug use among high school students. Most of these clinics had a policy board composed of housewives, businessmen, city officials, and professionals; a few had students on the board. Many centers began with a small amount of community funding. They generally offered drug care that was limited to education and counseling. Other types of counseling included problems with parents, school, and growing up.

The largest group of patients included 16- to 18-year-olds, but a few clinics also served a sizable 
number of 12 - to $15-$ or $19-$ to 24-year-olds. Patients came from all over the city and suburbs, and transients were rare. There were a few youth clinics that catered to young children under 12 years old; these did not offer any drug-related services.

Sponsored clinics. The fourth type of clinic was represented by the "youth clinics" run by the Los Angeles County Health Department, four of which were included in this survey (4). They were modeled after the street-type centers serving the same kind of patients; however, the average age of the sponsored patients was lower than that of the street centers' patients. Although there were some volunteer staff members in the sponsored clinics, vir- tually all the professionals were paid on an hourly basis.

\section{Clinic Services}

The services provided directly by 56 clinics are listed in table 2 . Although the medical staffs had dedicated and well-qualified practitioners-all but five clinics had specialists on their staffssome facilities were makeshift or poorly equipped and overcrowded with patients, resulting in a wide variation in the quality and level of care among clinics. Referrals were often made for types of care that could not be handled locally. Some clinics did not have the same physicians volunteering on a regular basis, which made continuity of patient care impossible.

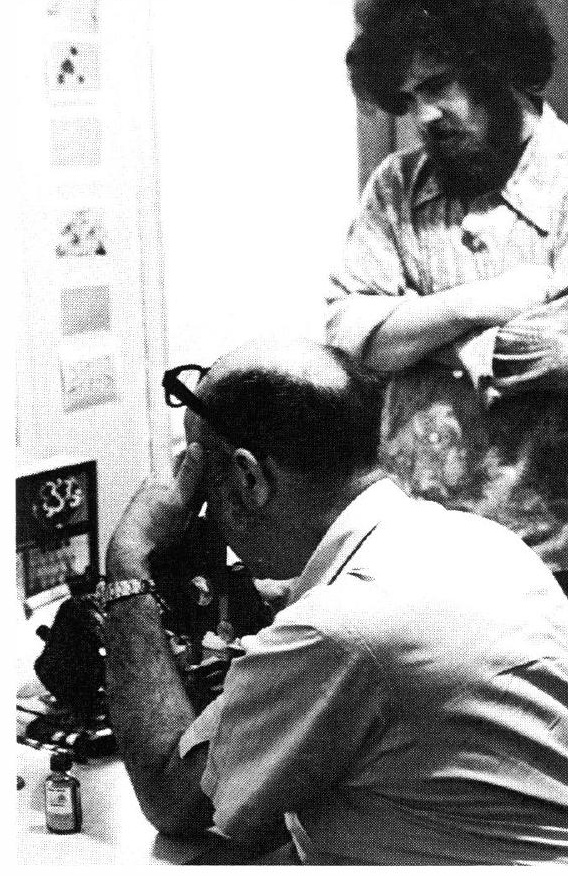

Laboratory at Barrio Free Clinic, Los Angeles. Many clinics have limited laboratories, some in former kitchens.

Table 2. Services provided, by type of free clinic, 1970

\begin{tabular}{|c|c|c|c|c|c|}
\hline Services & $\begin{array}{l}\text { All clinics } \\
(\mathrm{N}=56)\end{array}$ & $\begin{array}{c}\text { Street } \\
(\mathrm{N}=20)\end{array}$ & $\begin{array}{l}\text { Neigh- } \\
\text { borhood } \\
(\mathrm{N}=23)\end{array}$ & $\begin{array}{l}\text { Youth } \\
(\mathrm{N}=9)\end{array}$ & $\begin{array}{l}\text { Sponsored } \\
(\mathrm{N}=4)\end{array}$ \\
\hline \multicolumn{6}{|l|}{ Medical care by physicians: } \\
\hline Emergency care........... & 28 & 15 & 11 & 2 & 0 \\
\hline First-aid services.. & 51 & 20 & 19 & 8 & 4 \\
\hline Sick care.................. & 56 & 20 & 23 & 9 & 4 \\
\hline Insurance and school examinations. & 30 & 9 & 19 & 2 & 0 \\
\hline 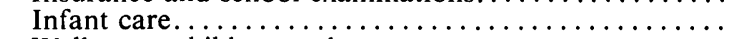 & 32 & 10 & 19 & 3 & 0 \\
\hline Well care, children and teenagers... & 34 & 9 & 22 & 3 & 0 \\
\hline Prenatal and postnatal care............ & 24 & 6 & 14 & 2 & 2 \\
\hline Obstetrical delivery................. & 4 & 2 & 1 & 1 & 0 \\
\hline Venereal disease..... & 50 & 19 & 19 & 8 & 4 \\
\hline Minor surgery....... & 12 & 5 & 5 & 1 & 1 \\
\hline \multicolumn{6}{|l|}{ Other medical services: } \\
\hline Immunizations......... & 37 & 9 & 23 & 3 & 2 \\
\hline Prescription drugs..... & 52 & 18 & 23 & 7 & 4 \\
\hline Laboratory tests..... & 45 & 17 & 17 & 7 & 4 \\
\hline Pregnancy tests........ & 42 & 15 & 16 & 7 & 4 \\
\hline Abortion counseling. . & 35 & 16 & 10 & 5 & 4 \\
\hline Family planning. .... & 36 & 17 & 9 & 6 & 4 \\
\hline Dental care................. & 11 & 4 & 6 & 1 & 0 \\
\hline \multicolumn{6}{|l|}{ Drug treatment or counseling: } \\
\hline Drug counseling $\ldots \ldots \ldots \ldots \ldots$ & 36 & 19 & 7 & 6 & 4 \\
\hline Drug education and information. & 35 & 17 & 8 & & 4 \\
\hline Drug detoxification............. & 18 & 12 & 4 & & 0 \\
\hline Drug rehabilitation. $\ldots \ldots \ldots \ldots \ldots \ldots \ldots$ & 15 & 10 & 3 & 2 & 0 \\
\hline \multicolumn{6}{|l|}{ Psychiatric or psychological treatment: } \\
\hline Individual counseling. . . . . . . . . & 35 & 16 & 9 & 6 & 4 \\
\hline Group counseling................. & 28 & 13 & 7 & 5 & 3 \\
\hline Psychotherapy (long-term) $\ldots \ldots \ldots \ldots \ldots \ldots \ldots \ldots \ldots$ & 11 & 7 & 2 & 1 & 1 \\
\hline \multirow{2}{*}{\multicolumn{6}{|c|}{ Miscellaneous: }} \\
\hline & & & & & \\
\hline Hotline or crisis telephone $\ldots \ldots \ldots \ldots \ldots \ldots \ldots$ & 19 & 16 & 1 & 2 & 0 \\
\hline Vocational guidance $\ldots \ldots \ldots \ldots \ldots \ldots \ldots \ldots \ldots \ldots$ & 16 & 11 & 2 & 2 & 1 \\
\hline 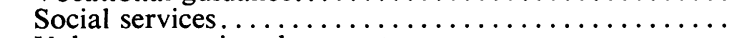 & 29 & 13 & 10 & $\overline{3}$ & 3 \\
\hline Volunteer service placement $\ldots \ldots \ldots \ldots \ldots \ldots \ldots \ldots$ & 7 & 4 & 2 & 0 & 1 \\
\hline 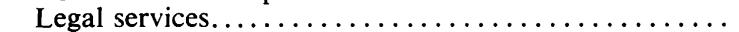 & 22 & 13 & 5 & 3 & 1 \\
\hline Draft counseling.......................... & 12 & 8 & 3 & 1 & 0 \\
\hline
\end{tabular}


Other medical care. At most clinics prescription drugs were dispensed to the patients from a drug closet stocked by donations from physicians, pharmaceutical houses, pharmacies, and hospitals. Some centers were well stocked with a variety of drugs while others had limited drug supplies. All the neighborhood programs gave immunizations, but less than half of the street and only three youth clinics offered them. Limited laboratories were set up in 45 centers, usually in former kitchens, but often specimens were taken to commercial laboratories, hospitals, or the health department. Half of the laboratories were staffed by experienced technicians; the others were operated by medical students, nurses, and community people.

Neighborhood centers generally made referrals to existing community programs for family planning and abortion counseling, but three out of four street clinics handled these services at their facilities. All four sponsored clinics dispensed prescription drugs and performed laboratory and pregnancy tests.

Dental care. Dental care was provided in 11 clinics-four street, six neighborhood, and one youth. At a few clinics referral

Emergency medical care is among services free clinics offer.

Barrio Free Clinic, Los Angeles

Physician care. Three services were generally available. All clinics offered care for acute illness, all but five provided first aid, and all but six offered treatment for venereal disease. Half of the centers gave emergency care, but only 12 did minor surgery. Three-fifths of the clinics offered well-child and teenage care, two-fifths gave prenatal and postnatal care, and slightly more than half did school and employment physical examinations and provided infant care. Many centers made referrals for obstetrical care, but only four made direct arrangements that covered delivery and hospitalization for the maternity patient.

A higher proportion of street clinics than other types of free clinics treated emergencies, while more neighborhood centers offered infant, well child care, prenatal services, and physical examinations. Youth clinics concentrated on first aid, sick care, and treatment of venereal disease.

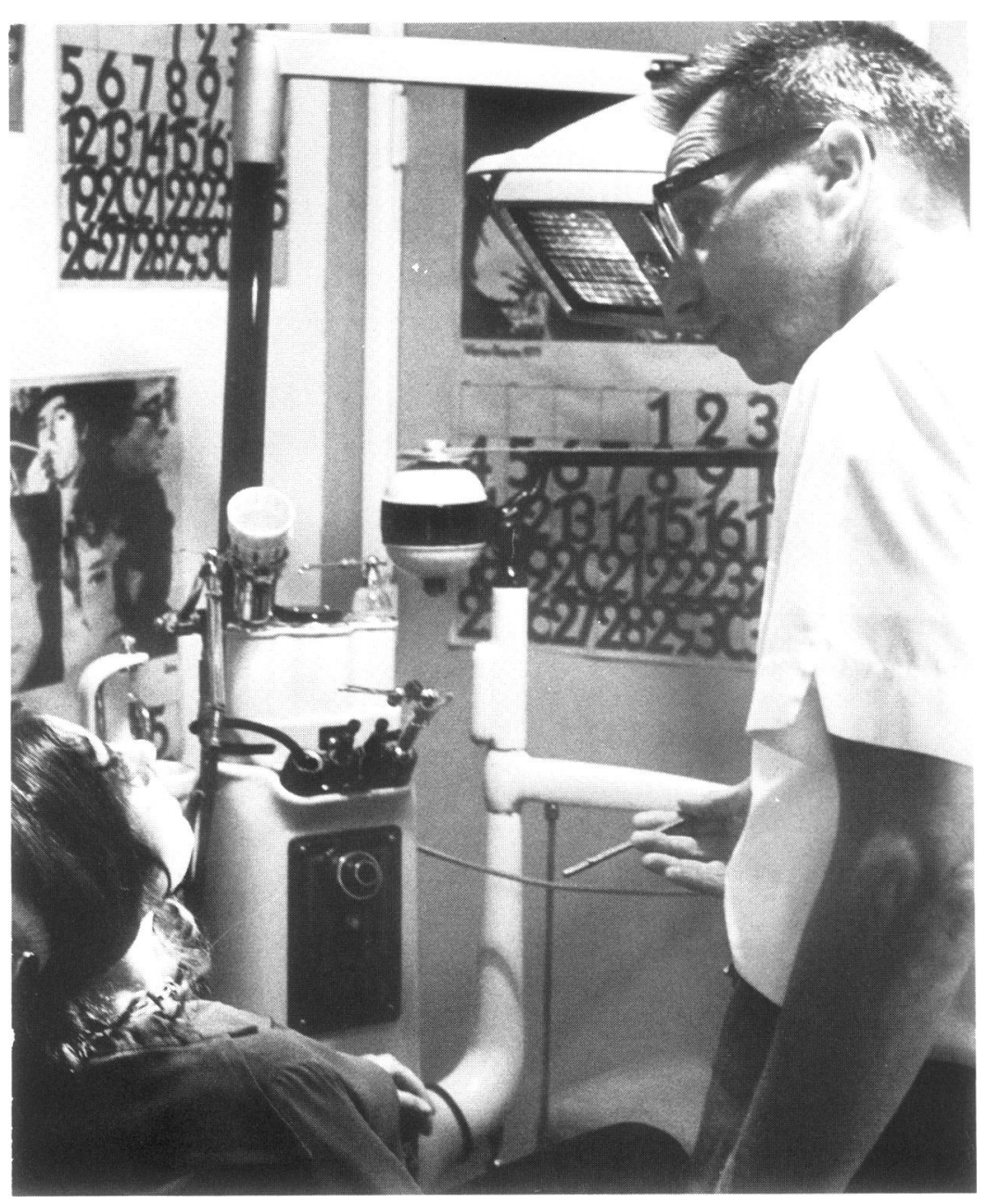

Dental care at the Barrio Free Clinic, Los Angeles 
arrangements were made with private dentists for free care. Three neighborhood clinics limited to dental care were not included in this report.

Drug care. Comprehensive drug care (counseling, education, detoxification, and rehabilitation) was available in only 12 clinics. Although eight of these were street clinics, it was surprising that the other street clinics had limited drug abuse programs since they were founded primarily to provide health care to young people, most of whom were using drugs. All but one street clinic offered drug counseling, but only half handled followup care for drug addiction. Most centers, however, made arrangements with hospitals or community addiction programs to accept patients needing detoxification services. The sponsored clinics limited themselves to counseling and education. Only four neighborhood clinics had detoxification or rehabilitation services, but two of these handled few drug cases.

Drug education and information services were available in $\mathbf{3 5}$ clinics, with the programs varying widely. Most centers displayed posters, distributed literature, and held rap sessions; others also sponsored lectures and showed films-all these activities taking place in the clinic. But some groups had an ongoing community program aimed at educating parents and the general public about drug abuse through forums, literature, television, newspaper articles, rap sessions at local schools, and a speaker's bureau.

Psychiatric or psychological services. Individual counseling for patients with problems was available in three-fifths of the clinics, while half of the clinics had group sessions. Although half of the clinics had psychiatrists, only 11 programs offered psychotherapy. Rap sessions on a variety of topics (sex, drugs, the draft, politics, "hangups," health care, abortion) were more often held in street centers.

Miscellaneous services. Many of the following nonhealth services were offered by free clinics, mostly the street type: schools with a variety of courses, remedial reading, tutoring, workshops, job placement, arts and crafts, drama, dance, yoga, youth activities, discussions, showers and "crash pads," field trips, recreation, free store (with a variety of items from food to furniture), laundry facilities, information centers, switchboards, messages, "women's lib" meetings and services, legal and health advocacy, and child care.

Some health-related services were nutrition education, eye and podiatry care, screening for diseases in the community, home visiting, health education, weight control, and classes for dietitians, health and nursing aides, and medical technicians. One clinic even offered pet care by volunteer veterinarians.

Many clinics made referrals for legal services, draft counseling, or social services, but 29 of the 56 clinics performed social services directly, 22 offered legal services and 12 provided draft counseling from the health center. Four of five street clinics ran their own crisis hotline, and half gave vocational guidance. Neighborhood clinics offered few extra services, but some were near community programs that sponsored legal, vocational, and mental health counseling.

\section{Diagnoses}

Although individual clinics varied, the most common diag- noses in street and sponsored centers were for venereal disease, birth control assistance, and pregnancy tests. Next were upper respiratory infections, urinary infections, drug problems, hepatitis, and dermatitis. Trauma, physical examinations, and miscellaneous infections completed the important diagnoses at these clinics. Although some illnesses treated were related to drug use, drug overuse or overt toxicity represented only a small portion of all diagnoses.

Neighborhood centers had a wider range of patients-from babies to aged persons. Therefore, the diagnoses were more diverse than in other types of clinics. Prenatal and well child care. respiratory infections, and urinary complaints were common diagnoses. Persons with venereal disease and family planning needs were often referred to other community facilities. Other major diagnoses included chronic disease, trauma, and physical examinations.

Youth clinics treated many patients for venereal disease, but handled more patients for infections and skin problems and fewer for birth control and pregnancy tests than street clinics. A significant amount of preventive care, including immunizations and school and camp physical examinations, was provided by the youth clinics.

\section{Clinic Hours and Utilization}

Scheduled hours. Medical care was available an average of 14.5 hours per week in free clinics, primarily in the evening because it was difficult to recruit volunteer professionals to work daytime hours (table 3). During scheduled hours a physician was expected to be present, but if that physician could not attend, others were called. Sometimes a ses- 
Table 3. Scheduled hours and sessions per week of medical services, by type of free clinic, 1970

\begin{tabular}{|c|c|c|c|c|c|}
\hline Hours and sessions & $\begin{array}{l}\text { All clinics } \\
(\mathrm{N}=56)\end{array}$ & $\begin{array}{c}\text { Street } \\
(N=20)\end{array}$ & $\begin{array}{l}\text { Neighborhood } \\
(\mathrm{N}=23)\end{array}$ & $\begin{array}{l}\text { Youth } \\
(\mathrm{N}=9)\end{array}$ & $\begin{array}{l}\text { Sponsored } \\
(\mathrm{N}=4)\end{array}$ \\
\hline 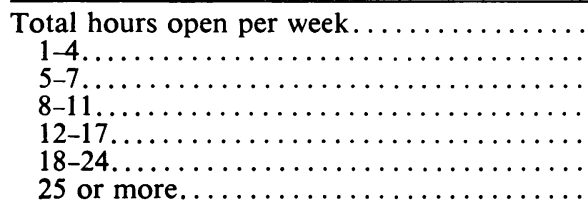 & $\begin{array}{c}813.5 \\
6 \\
4 \\
11 \\
19 \\
8 \\
8\end{array}$ & $\begin{array}{c}341.5 \\
0 \\
0 \\
4 \\
7 \\
5 \\
4\end{array}$ & $\begin{array}{c}260.5 \\
5 \\
3 \\
4 \\
8 \\
2 \\
1\end{array}$ & $\begin{array}{c}141.0 \\
1 \\
1 \\
3 \\
2 \\
0 \\
2\end{array}$ & $\begin{array}{l}70.5 \\
0 \\
0 \\
0 \\
2 \\
1 \\
1\end{array}$ \\
\hline 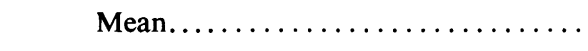 & 14.5 & 17.1 & 11.3 & 15.7 & 17.6 \\
\hline 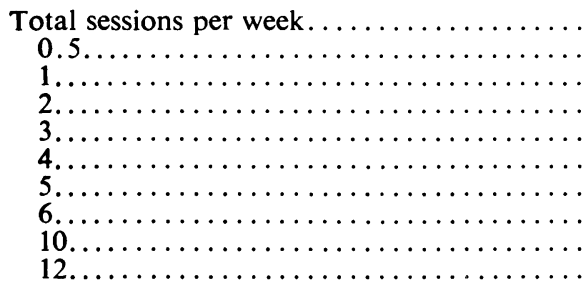 & $\begin{array}{r}228.5 \\
1 \\
5 \\
6 \\
11 \\
7 \\
16 \\
8 \\
1 \\
1\end{array}$ & $\begin{array}{l}96.0 \\
0 \\
0 \\
1 \\
5 \\
1 \\
7 \\
5 \\
1 \\
0\end{array}$ & $\begin{array}{l}79.0 \\
0 \\
5 \\
5 \\
2 \\
5 \\
4 \\
1 \\
0 \\
1\end{array}$ & $\begin{array}{l}37.5 \\
1 \\
0 \\
0 \\
2 \\
1 \\
3 \\
2 \\
0 \\
0\end{array}$ & $\begin{array}{l}16.0 \\
0 \\
0 \\
0 \\
2 \\
0 \\
2 \\
0 \\
0 \\
0\end{array}$ \\
\hline Mean... & 4.1 & 4.8 & 3.4 & 4.2 & 4.0 \\
\hline 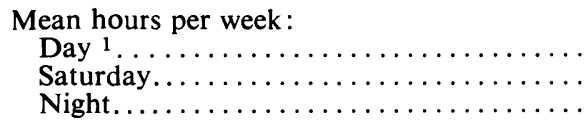 & $\begin{array}{r}34.5 \\
10.0 \\
184.0\end{array}$ & $\begin{array}{r}13.0 \\
6.0 \\
77.0\end{array}$ & $\begin{array}{r}16.0 \\
3.0 \\
60.0\end{array}$ & $\begin{array}{r}5.5 \\
1.0 \\
31.0\end{array}$ & $\begin{array}{c}0 \\
0 \\
16.0\end{array}$ \\
\hline
\end{tabular}

1 Day session is one that ended by 6 p.m.

sion had to be cancelled or limited to services that could be handled by nurses, medical students, and other volunteers.

More than half of all clinics were open for medical care from 8 to 17 hours per week. Street and sponsored centers scheduled more hours of medical care than did the other two types; all street clinics were open at least 8 hours weekly, and nine were open at least 18 hours; four of these were open at least 25 hours per week. Only three neighborhood clinics were open as much as 18 hours; five were open just 3 or 4 hours per week. The youth clinics averaged 15.7 hours weekly.

Sessions. The average number of sessions per week for medical care did not vary too much between types of clinics; individually, however, there was variation (table 3 ). Of the total sessions, 81 percent were held at night, 15 percent during the day, and 4 percent on Saturdays. A higher proportion of neighbor- hood and youth than street clinic sessions was held in the daytime.

Patients served. As indicated by their longer hours and greater number of sessions, street clinics averaged more patients than the other centers (table 4). All street clinics had caseloads of 100 patients per month, whereas five neighborhood and two youth clinics served 100 or less patients monthly. Three-fifths of the

Table 4. Average number of medical patients served per month, by type of free clinic, 1970

\begin{tabular}{|c|c|c|c|c|c|}
\hline Number served & $\begin{array}{c}\text { All } \\
\text { clinics } \\
(N=56)\end{array}$ & $\begin{array}{c}\text { Street } \\
(\mathrm{N}=21)\end{array}$ & $\begin{array}{c}\text { Neigh- } \\
\text { bor- } \\
\text { hood } \\
(\mathrm{N}=21)\end{array}$ & $\begin{array}{l}\text { Youth } \\
(\mathrm{N}=10)\end{array}$ & $\begin{array}{l}\text { Spon- } \\
\text { sored } \\
(\mathrm{N}=4)\end{array}$ \\
\hline 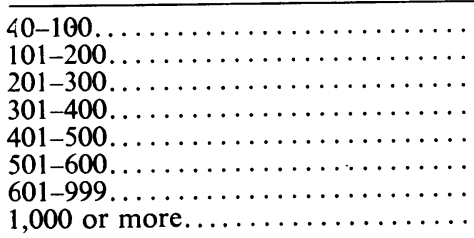 & $\begin{array}{r}7 \\
11 \\
10 \\
12 \\
4 \\
3 \\
4 \\
5\end{array}$ & $\begin{array}{l}0 \\
5 \\
3 \\
2 \\
3 \\
1 \\
2 \\
5\end{array}$ & $\begin{array}{l}5 \\
2 \\
7 \\
6 \\
0 \\
1 \\
0 \\
0\end{array}$ & $\begin{array}{l}2 \\
4 \\
0 \\
3 \\
1 \\
0 \\
0 \\
0\end{array}$ & $\begin{array}{l}0 \\
0\end{array}$ \\
\hline $\begin{array}{l}\text { Mean patients per month....... } \\
\text { Median patients per month.... }\end{array}$ & $\begin{array}{l}358.6 \\
312.5\end{array}$ & $\begin{array}{l}471.4 \\
483.0\end{array}$ & $\begin{array}{l}254.8 \\
250.0\end{array}$ & $\begin{array}{l}234.0 \\
200.0\end{array}$ & $\begin{array}{l}623.7 \\
660.0\end{array}$ \\
\hline
\end{tabular}


nights and the other two open 5 nights per week. The sponsored clinics were popular; the smaller ones averaged between 325 and 520 patients per month and the larger ones, around 800 per month.

\section{Patients' Characteristics}

Street and sponsored clinics served mainly white, middleclass, long-haired patients between 19 and 22 years of age. Youth clinics catered to the white, middle-class adolescent. On the other hand, neighborhood clinics served the minority patient, generally older persons, pregnant women and teenage girls, and young children.

Sex. The patients in youth, sponsored, and street clinics were fairly evenly distributed between the sexes; a few clinics of each type served more females (60 percent) while a few others served more males. In 20 neighborhood clinics, female patients were predominant (at least 60 percent) in five and were the majority in six others; male patients were the majority in only two clinics.

Ages. The ages of patients served by the different types of clinics differed, with the youth centers seeing the youngest patients. The 16- to 18-year age group was predominant in youth clinics; in seven of nine youth clinics more than 35 percent of the patients were in this age group. Street and sponsored clinics treated mainly the 19- to 24year-old patients; one-fifth of the street clinics served a substantial proportion of 16- to 18-year-olds, and one had many 25- to 34year old patients.

Neighborhood clinics catered to families, with persons over 35 years old and children under 12 predominant; adolescents repre- sented the smallest proportion, and there was a moderate number of women patients 19 to 34 years old. Youth clinics treated virtually no patients over 35 years old; street and sponsored clinics had a sprinkling of older patients, generally less than 5 percent.

Ethnic groups. The white patient was predominant in street and sponsored centers, whereas neighborhood clinics served mainly the minority patient. Patients in only one street center were at least 25 percent black, while of 23 neighborhood centers, 18 had at least 40 percent black patients and two had at least 80 percent Spanish-speaking patients. Six neighborhood clinics had 80 percent black patients, and five served black patients entirely. Four neighborhood clinics with a majority of white patients served Appalachian whites. Two of 10 youth centers had at least 25 percent black patients. Of all clinics founded between 1967 and 1969, two had a patient load that included 15 percent American Indians, while five served from 1 to 5 percent Indian patients. Only one clinic had as many as 10 percent oriental patients, and two others served less than 5 percent oriental patients.

\section{Physician Volunteers}

Participating physicians. A total of 917 physicians served in

Indian nurse and child at the American Indian Free Clinic in Los Angeles, the first such agency especially for urban Indians

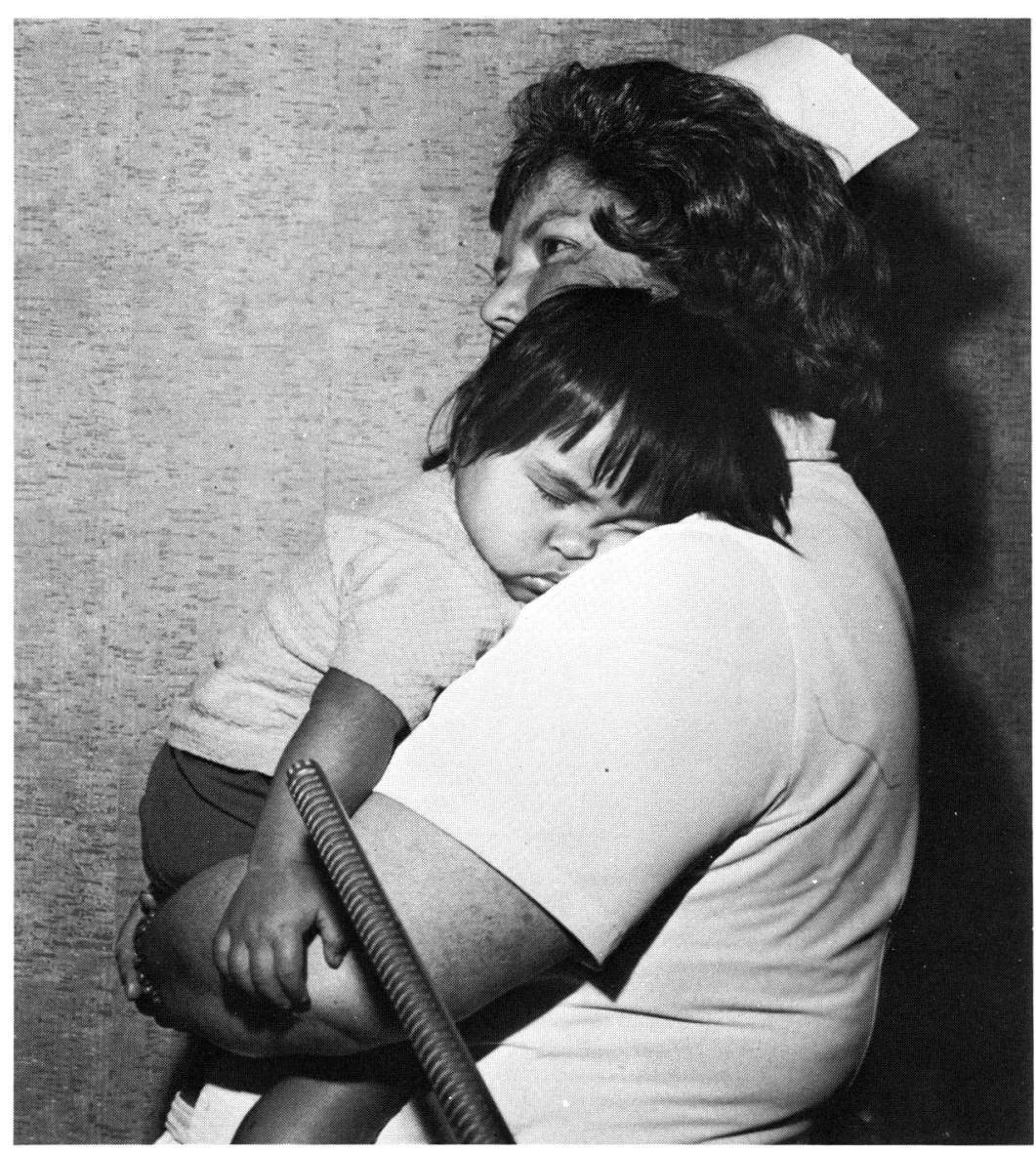


Table 5. Distribution of participating physicians, by type of free clinic, 1970

\begin{tabular}{|c|c|c|c|c|c|}
\hline Number of physicians ${ }^{1}$ & $\begin{array}{c}\text { All } \\
\text { clinics } \\
(\mathrm{N}=54)\end{array}$ & $\begin{array}{c}\text { Street } \\
(\mathrm{N}=20)\end{array}$ & $\begin{array}{l}\text { Neigh- } \\
\text { borhood } \\
(\mathrm{N}=21)\end{array}$ & $\begin{array}{l}\text { Youth } \\
(N=9)\end{array}$ & $\begin{array}{l}\text { Sponsored } \\
(\mathrm{N}=4)\end{array}$ \\
\hline 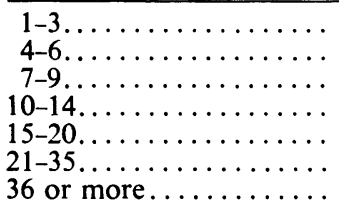 & $\begin{array}{r}3 \\
8 \\
9 \\
10 \\
11 \\
4 \\
9\end{array}$ & $\begin{array}{l}2 \\
0 \\
2 \\
4 \\
3 \\
2 \\
7\end{array}$ & $\begin{array}{l}0 \\
6 \\
4 \\
3 \\
6 \\
1 \\
1\end{array}$ & $\begin{array}{l}1 \\
1 \\
1 \\
2 \\
2 \\
1 \\
1\end{array}$ & $\begin{array}{l}0 \\
1 \\
2 \\
1 \\
0 \\
0 \\
0\end{array}$ \\
\hline $\begin{array}{l}\text { Mean } \ldots \ldots \ldots \ldots \ldots \\
\text { Median........... }\end{array}$ & $\begin{array}{l}17.4 \\
13.5\end{array}$ & $\begin{array}{l}24.5 \\
18.0\end{array}$ & $\begin{array}{l}12.9 \\
10.0\end{array}$ & $\begin{array}{l}16.0 \\
12.0\end{array}$ & $\begin{array}{l}8.0 \\
9.0\end{array}$ \\
\hline
\end{tabular}

1 Includes medical and psychiatric physicians.

53 free clinics. The average and median number of physicians was greater in street than in other clinic types (table 5). Of the participating physicians, 53 percent worked in street clinics, 27 percent in neighborhood clinics, 16 percent in youth clinics, and 3.5 percent in sponsored clinics. Although two street clinics had only one or two physicians, seven street clinics had 36 or more physicians. Only one each of the neighborhood and youth clinics had as many as 36 physicians. In all, 37 percent of the clinics had nine or fewer participating physicians, 39 percent had 10 to 20 physicians, and 24 percent had more than 20 .
Types of physicians. Some of the larger clinics drew more interns and residents, as well as physicians, from medical schools than from private practice. About 10 percent of the physicians were interns and 14 percent were residents (table 6). There were no interns and only a few residents in youth clinics; but more than half of the physicians in sponsored clinics, about a third in neighborhood clinics, and onefourth in street clinics were residents and interns.

General practitioners accounted for one-eighth of all the physicians. Neighborhood and youth clinics had proportionately more general practitioners than street clinics. Street clinics had the highest proportion of psychiatrists, and neighborhood and sponsored centers, the least.

Three of five physicians participating in youth clinic programs were medical specialists as compared with about two of five in the other three types of clinics. Internists were the leading specialists in all but the sponsored clinics, which had a greater porportion of pediatricians. Street and neighborhood clinics had a wide variety of specialists, the highest number (after the three most common specialists) being surgeons, dermatologists, and ophthalmologists. Many specialists, including radiologists, pathologists, neurosurgeons, and psychiatrists, practiced general medicine.

Time donated by physicians. All physician time was paid in sponsored clinics. Of approximately 7,000 hours worked monthly by physicians in the other clinics, only about 7 percent of the hours were paid, and the remaining time was donated. The amount of contributed hours was considerable, reaching more than 6,000 per month. Of all physician time worked in the free clinics, 12

Table 6. Participating physicians, by type of free clinic, 1970

\begin{tabular}{|c|c|c|c|c|c|c|c|c|c|c|}
\hline \multirow{2}{*}{ Type of physician } & \multicolumn{2}{|c|}{$\begin{array}{l}\text { All clinics } \\
(\mathrm{N}=53)\end{array}$} & \multicolumn{2}{|c|}{$\begin{array}{c}\text { Street } \\
(\mathrm{N}=20)\end{array}$} & \multicolumn{2}{|c|}{$\begin{array}{l}\text { Neighborhood } \\
(\mathrm{N}=20)\end{array}$} & \multicolumn{2}{|c|}{$\begin{array}{l}\text { Youth } \\
(\mathrm{N}=9)\end{array}$} & \multicolumn{2}{|c|}{$\begin{array}{l}\text { Sponsored } \\
(\mathrm{N}=4)\end{array}$} \\
\hline & $\underset{\text { ber }}{\text { Num- }}$ & $\begin{array}{l}\text { Per- } \\
\text { cent }\end{array}$ & $\underset{\text { ber }}{\text { Num- }}$ & $\begin{array}{l}\text { Per- } \\
\text { cent }\end{array}$ & $\underset{\text { ber }}{\text { Num- }}$ & $\begin{array}{l}\text { Per- } \\
\text { cent }\end{array}$ & $\underset{\text { ber }}{\text { Num- }}$ & $\begin{array}{l}\text { Per- } \\
\text { cent }\end{array}$ & $\begin{array}{c}\text { Num- } \\
\text { ber }\end{array}$ & $\begin{array}{l}\text { Per- } \\
\text { cent }\end{array}$ \\
\hline 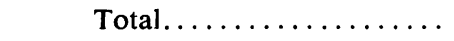 & 917 & 100.0 & 490 & 100.0 & 251 & 100.0 & 144 & 100.0 & 32 & 100.0 \\
\hline 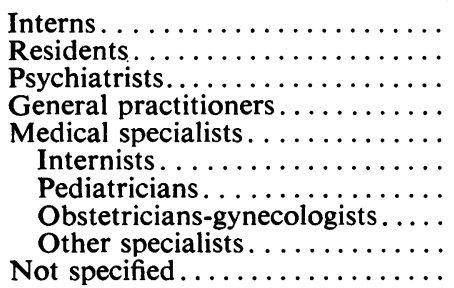 & $\begin{array}{r}88 \\
129 \\
93 \\
113 \\
412 \\
137 \\
87 \\
75 \\
113 \\
82\end{array}$ & $\begin{array}{r}9.6 \\
14.1 \\
10.1 \\
12.3 \\
44.9 \\
14.9 \\
9.5 \\
8.2 \\
12.3 \\
8.9\end{array}$ & $\begin{array}{r}52 \\
71 \\
68 \\
45 \\
209 \\
64 \\
32 \\
41 \\
72 \\
45\end{array}$ & $\begin{array}{r}10.6 \\
14.5 \\
13.9 \\
9.2 \\
42.7 \\
13.1 \\
6.5 \\
8.4 \\
14.7 \\
9.2\end{array}$ & $\begin{array}{r}34 \\
37 \\
9 \\
46 \\
103 \\
31 \\
24 \\
17 \\
31 \\
22\end{array}$ & $\begin{array}{r}13.5 \\
14.7 \\
3.6 \\
18.3 \\
41.0 \\
12.4 \\
9.6 \\
6.8 \\
12.4 \\
8.8\end{array}$ & $\begin{array}{r}0 \\
7 \\
15 \\
21 \\
86 \\
39 \\
25 \\
15 \\
7 \\
15\end{array}$ & $\begin{array}{r}4.9 \\
10.4 \\
14.6 \\
59.7 \\
27.1 \\
17.4 \\
10.4 \\
4.9 \\
10.4\end{array}$ & $\begin{array}{r}2 \\
14 \\
1 \\
1 \\
14 \\
3 \\
\cdot \quad 6 \\
2 \\
3 \\
0\end{array}$ & $\begin{array}{r}6.3 \\
43.8 \\
3.1 \\
3.1 \\
43.8 \\
9.4 \\
18.8 \\
6.3 \\
9.4 \\
\ldots \ldots\end{array}$ \\
\hline
\end{tabular}


percent of the hours were worked by residents, 6 percent by interns, 10 percent by psychiatrists, and 72 percent by all other physicians. The number of hours donated by physicians varied greatly. A few worked long hours (50 to 100 hours monthly), but some worked only once a month or once in 6 weeks.

Medical directors. The role of the medical director differed among clinics; typically he worked out policies dealing with medical care (for example, treatment for venereal disease, malpractice liability coverage). A few medical directors largely decided program policies, but generally these policies were decided by the entire staff, board members, and some community people.

One medical director served the four sponsored clinics. Of the other 55 free clinics, 12 (two street, nine neighborhood, one youth) did not have a medical director, but two street centers had two medical directors. Twenty directors were in private practice, 12 were on university faculties, eight were in public health, two came from public hospitals, four were from' other hospitals, one director had no affiliation other than the free clinic, and one was a student; the affiliation of one director was unknown.

Nine medical directors were general practitioners, and one each was an osteopath, an intern, a public health student, and a radiology resident. Twenty-nine of the medical directors were specialists: eight were internists, eight pediatricians, four psychiatrists, and two each were obstetricians-gynecologists and neurologists; the other five specialists included a urologist, a neurosurgeon, a pharmacologist, a chest surgeon, and a general surgeon.
(The specialty of three directors was not known.) Eight medical directors received some compensation from the clinics (five street, one neighborhood, and two youth).

\section{Paid Staff}

Most free clinic workers were volunteers; particularly, the professional staff. Almost all clinics were formed without funding, and in the beginning all staff members were volunteers. After donations were received or a small grant secured, salaries were paid to a few staff members. However, salaries were generally low and the number of hours worked and donated, large.

All staff except a few community volunteers were paid in the four sponsored clinics. In each of the 10 youth centers, some member of the staff was compensated, but in four street and seven neighborhood centers, no one was paid; all staff members were volunteers. The admin-

Freedom from hassle and red tape as well as free care have attracted alienated youth, the poor, and minorities to centers like Barrio Free Clinic in Los Angeles

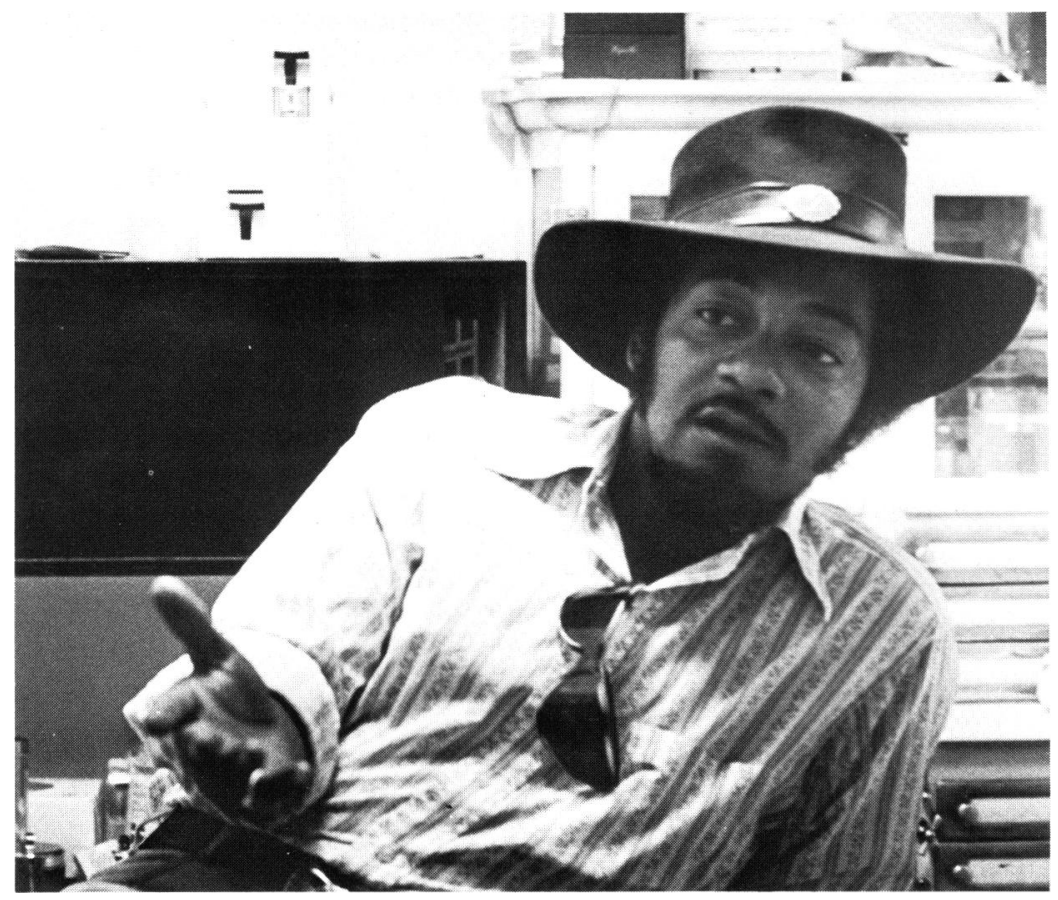

istrator was the staff member most frequently paid. He was compensated in 31 of 54 clinics, and in three street, three neighborhood, and two youth clinics he was the only one paid. Next to the administrator, the staff member most frequently paid in neighborhood centers was the community aide; he was compensated in eight clinics.

Although salaries were low, a higher proportion of street centers than other types paid some staff members. In 14 clinics (18 if the four sponsored centers are included) one or more physicians were paid: six street, five neighborhood, and three youth. Three street clinics paid annual salaries to one physician each, as follows: $\$ 6,000$ for 15 hours per week, $\$ 7,200$ for 20 hours per week, and $\$ 18,000$ for full time. One neighborhood clinic paid physicians $\$ 50$ per session, and one paid medical residents $\$ 12.50$ per hour. 


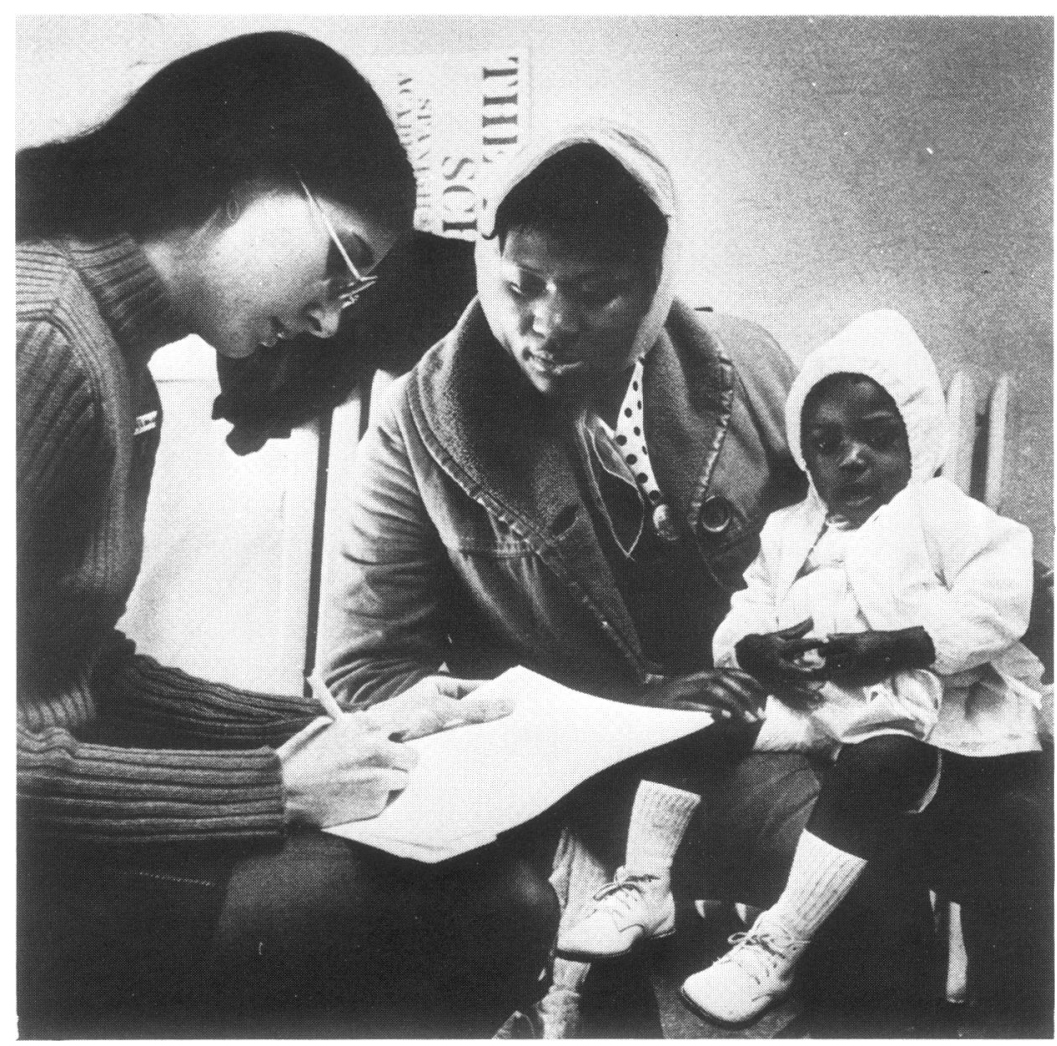

Young worker gets some information about a mother and child at the Young Patriots' Community Health Service. Photo by Paul Sequeira

Of the 55 clinics, 20 paid a community aide, 11 paid a secretary, and eight compensated the person doing maintenance or cleaning. Other paid staff members included registered nurses in 10 clinics, licensed practical nurses in two, laboratory technicians in two, and social workers or professional counselors in eight.

In addition to persons paid from the clinic's budget, personnel (including three physicians) in seven clinics-one street, five neighborhood, and one youthreceived pay from other sources.

\section{Comment}

Free clinics arose from the need for medical care on the part of population groups that were not receiving proper nor sufficient attention: adolescents, alienated middle-class college dropouts, must travel on several buses with inirequent service, and often he cannot afford the bus fare. Generally the patient must also travel to several different locations, as each public clinic is limited in the scope of care it can offer. Daytime hours of public clinics often inconvenience the mothers of small children if they must travel long distances and endure long waits for care.

A common complaint is the disrespect, lack of courtesy, and scant privacy found in public clinics. Other objections include overcrowded and sometimes dirty surroundings, long waits, cultural barriers, and fragmentation of care. Furthermore, alienated young people who use drugs fear public hospitals and health clinics as institutions that not only cooperate with the police but scorn and abuse the long-haired patient and pose judgments on him.

For these and other reasons, the poor have sought to establish their own programs. Although the service is far from comprehensive, the facilities grossly inadequate, and the equipment meager, the volunteer physicians and nurses working alongside community people show respect and compassion for the free clinic patients. Both the longhaired and the minority patients resent the eligibility procedures, redtape, and hassle encountered in public clinics. It is in this regard that all free clinics, whether street, youth, neighborhood, or sponsored, are similar: they are free of redtape and questions. "Free" does not only mean no charge but free of eligibility requirements, questions, and bureaucratic hassle.

Free clinics have shown they can survive. All but nine of the 59 established during 1967-69 were still providing medical serv- 
ices at the end of 1970. However, the clinics have been beset with problems, and foremost is operating on a shoestring. Some clinics have secured substantial foundation or public grants, but there is the eventual problem of refunding; for those with insufficient funding there is the constant search for contributions and grants. Some clinics are beginning to collect from Medicaid, but this forces them to identify welfare patients and to begin asking questions.

Operating with volunteer professionals is tenuous because there is constant pressure to locate and schedule a full range of professionals. Many clinics find it more difficult to recruit nurses or laboratory technicians than physicians. The flow of volunteers is erratic.

Some clinics have regularly scheduled physicians, but with a volunteer staff continuity of care is difficult to provide. A few neighborhood clinics, in an attempt to provide continuity, are beginning to pay physicians and nurses for work done on a specific schedule. Clinic hours, however, are limited in most centers, so unless the patient becomes ill on an evening the clinic is open, he must wait until it is open or seek care at the public clinic.

Other problems arise from crowded and inadequate facilities, use of older equipment, makeshift examining rooms or laboratory facilities, and shortages of supplies and drugs.

The free clinic movement is dynamic and spreading, as evidenced by the addition of 60 new clinics in 1970; free clinics are receiving about 35,000 visits per month from patients. These clinics combine the initiative and organization of neighborhood people with the donation of profes- sional time. The free clinic has gone beyond the mere provision of care at no cost. It has been innovative in designing programs that did not exist elsewhere in the community, such as the methods of handling drug problems, the establishment of facilities in neighborhoods and housing projects, and door-to-door medical screening. The real success of the clinics lies in their identification with patients, and the patients' identification with them.

American medicine is witnessing yet another way of providing health care-one that is a unique solution to the problem of serving the poor, the minority person, and the alienated youth. These clinics are a phenomenon, and they deserve notice.

\section{Summary}

Fifty-nine free medical clinics were initiated in 1967-69 in all sections of the United States and in Canada. In a national survey, these centers were classified into four broad types: neighborhood, street, youth, and sponsored. Neighborhood clinics served primarily minority persons; street and sponsored clinics served the white, middle-class, long-haired patients; and youth clinics served white adolescents.

A wide range of medical, dental, psychiatric, drug abuse, and miscellaneous services were provided. The most common diagnoses in street and sponsored centers were venereal disease, birth control assistance, and pregnancy tests, with infections and drug problems next. Neighborhood centers had a wide range of patients, and diagnoses were therefore more diverse than in the other types of clinics.

Patient caseloads varied by clinic from less than 100 to more than 1,000 visits per month with physicians, and most clinic sessions were held at night. About 7,000 hours were worked monthly by physicians, all but 7 percent being donated. Of the participating physicians, 10 percent were interns, 14 percent residents, 10 percent psychiatrists, 12 percent general practitioners, 45 percent specialists, and 9 percent not specified.

Patient participation in deciding program policies varied by type of clinic, with the most participation in neighborhood centers and the least in youth and sponsored clinics. In many programs the entire staff had a major role in policymaking. Most clinics were founded without funding; therefore, the professional and auxiliary staffs were made up of volunteers, although small salaries were paid to a few staff members.

Free clinics are spreading, as evidenced by 60 new ones in 1970 and the handling of 35,000 patient visits per month. Free clinics developed from the need for medical care of certain population groups. These clinics have been innovative, and they have demonstrated a new style of providing medical care.

\section{REFERENCES}

(1) Schwartz, J. L.: Preliminary observations of free clinics. In The free clinic: A community approach to health care and drug abuse, edited by D. Smith, D. Bentel, and J. Schwartz. STASH Press, Beloit, Wis. In press.

(2) Smith, D. C., and Rose, A. J.: Observations in the Haight-Ashbury medical clinic of San Francisco: Health problems in a "hippie" subculture. Clin Pediat 7: 313-316, June 1968.

(3) Smith, D., and Bentel, D.: A new phenomenon has appeared. Calif Health 27: 1-4, April 1970.

(4) Hurley, A.: Los Angeles County turns youth on with a new brand of medical care. Calif Health 28: 6-9, September 1970. 